\title{
Cumhuriyet Dönemi Türk Eğitim Tarihi Alanında Yayınlanmış Türkçe Kitaplar Bibliyografyası
}

\section{Volkan TUNÇ*}

Özet: Eğitim geçmişten günümüze kadar bireylerin ve toplumların hayatlarına yön veren en önemli unsurlardan biridir. Özellikle insanın eğitime muhtaç olması ve eğitilebilir olması sebebiyle eğitim, birey ve toplumların hayatlarında vazgeçilemez bir yere sahiptir. Çünkü eğitim, tüm insanlığın nesiller boyunca edindiği bilgiler üzerine bir şeyler inşa ederek daha sonraki nesillere ulaştırdığ birikimdir. Tarih anlayışı da bu bilgi birikimi içerisinde önemli bir yere sahiptir. Çünkü tarih tüm uygarlıkların ortak bilincidir. Birey geçmişini hatırlamadığı takdirde bugününe ve geleceğine yön veremeyeceğine göre; toplumlar ve devletler de tarihlerini bildikleri takdirde bugünlerine ve geleceklerine yön verebileceklerdir. Aynı şekilde uygarlıkların kendi eğitim faaliyet geçmişini doğru bilmesi ve analiz etmesi günümüz eğitim faaliyetlerini doğru değerlendirmesine ve geleceğe yönelik yapılan planların daha sağlıklı ve uzun ömürlü yapılmasını sağlayacaktır. Bu bağlamda özellikle geçmişteki eğitim faaliyetleri noktasında kişilerin, kurumların, projelerin, programların iyi ve kötü yanlarıyla doğru analiz edilmesi yeni ve çağdaş eğitim fikirlerinin ortaya çıkmasında önemli bir rol oynayacaktır.

Bu çalışmada 1923 - 2018 yılları arasında kaleme alınan Türk Eğitim Tarihi konusunu ihtiva eden eserlerin bibliyografyası hazırlanmaya çalışılmıştır. Osmanlı Devleti sonrasında kurulan Cumhuriyet Türkiye'sinde birçok alanda olduğu gibi eğitim alanında da önemli eksiklikler bulunduğu kabul edilmektedir. Bu eksikliklerin giderilmesi için eğitim alanındaki önemli şahsiyetler tarafından farklı proje ve çalışmalar gerçekleştirilmiştir. Bu şahsiyetler, projeler, çalışmalar, programlar, sorunlar ve sorunların giderilmesi üzerine birçok eser kaleme alınmıştır. Türk Eğitim Tarihiyle alakalı olan tüm bu çalışmalar dikkatlice incelenmiştir. Çalışmada konuyla ilgili başta araştırma eserleri olmak üzere süreli yayınlar ve kütüphane katalogları taranmıştır.

Anahtar Kelimeler: Türk Eğitim Tarihi, Eğitim, Tarih, Bibliyografya, Literatür Tarama.

\footnotetext{
* Arş. Gör., Van Yüzüncü Yıl Üniversitesi, Eğitim Fakültesi, Türkçe ve Sosyal Bilimler Bölümü, Tarih Öğretmenliği ABD. Email: volkan_tunc23@hotmail.com Orcid No: 0000-0003-4639-9670.
}

Gönderim:26.12.2018 Kabul:19.02.2019 $\quad$ Yayın:15.03.2019




\title{
Bibliography of Turkish Books on History of Turkish Education Published in Republican Period
}

\begin{abstract}
Education is one of the most important elements that shapes individuals' and societies' lifes. Education, with the aspects of people can be educated and needed it- has an enormous place that nothing can replace it. Because education is a legacy that humanity builds and transfers to other generations. The understanding of history has an important place in that legacy. As the individuals who cannot understand their past cannot shape their future, societies and states can shape their today and tomorrow with knowledge on history. As same if civilizations know and analyze their history of education activity, they will build a long-term and well educated activities. In this context analyzing people, institutions, projects and programmes correctly with strong and weak points, will make new and contemporary ideas to come about.

In this study the publications on History of Turkish Education are shown. As on the other departments there were gaps on education in Republican Period Turkey that established after Ottoman Empire. To eliminate those deficiencies, important projects are developed by noteworthy people. Lots of publications are written on projects, studies, problems and on elimination of the problems. All those publications are examined carefully. In this study, primarily researches, publications and library catalogs are analyzed.
\end{abstract}

KeyWords: History of Turkish Education, History, bibliography, literature review. 


\section{GíRIŞ}

Bütün araştırmalarda konu seçimi ve sonraki aşamalar da dâhil olmak üzere yapılaması gereken en önemli unsurdan biri literatür çalışmasıdır. Çünkü araştırmacının belirlediği konu üzerinde daha önceden bir çalışma yapılıp yapılmadığını belirlemesi gerekmektedir. $\mathrm{Bu}$ bağlamda literatür çalışmasının ne denli önemli olduğu daha çalışmanın ilk aşamasında ortaya çıkmaktadır. Bunun yanı sıra araştırmacı literatür çalışması sonrasında belirlediği konu hakkında benzerlik gösteren çalışmaları tespit ederek bu kaynakları inceleme, analiz ve değerlendirme aşamalarından geçirerek kendi çalışmasında yararlanacağı kaynakları ve çalışmasındaki yöntemi belirlemesi gerekmektedir. Ancak bu çalışmanın sadece çalışmanın başında değil özellikle tez ve kitap gibi uzun bir süreçte yazılarak ortaya çıkan çalışmalarda ara ara tekrarlanması muhakkak gerekmektedir. Çünkü bu uzun süreçte yeni bir eserin yayınlanması veya elde edilen kaynaklardaki incelemeler sonrasında farklı bir kaynağa ulaşılması sıklıkla karşılaşılan bir durumdur. Bu minvalde çalışmanın gerçek anlamda salahiyeti için literatür çalışmasını tekrarlamak oldukça önemlidir. Ancak bir kısım araştırmacı literatür çalışmasını fazla önemsemeyerek zaman kaybı olarak görmekte ve bu nedenle de bu aşamayı hızlıca geçmektedir. Bu durum ise çalışmanın ilerleyen aşamasında ciddi problemlere ve karışıklıklara neden olmaktadır. Bu nedenle bilimsel çalışmaların temelini oluşturan bu tarama gayet ciddi ve özenle yapılması gereken bir aşamadır. Tüm bu etkenler göz önüne alınarak bibliyografya çalışmaları, araştırmacıların zaman ve emek kaybını azaltarak daha kısa sürede daha verimli, düzenli ve sistematik çalıșmalar yapmalarına katkıda bulunmak amacıyla hazırlanmaktadır.

Tarih ve eğitim alanlarında bu tarz çalışmalar bulunmakla birlikte yapılan literatür incelemesinde Türk Eğitim Tarihi alanında Mustafa Ergün'ün hocanın 2008 yılında Türkiye Araştırmaları Literatür Dergisi’nin 6. cilt, 12. sayısında yayınlanmış olan “Cumhuriyet Dönemi Eğitim Tarihi” adlı makale dışında bir çalışmaya rastlanmamıştır. Buna karşın, adı geçen makale ile yapılan çalışma muhteva bakımından birbirinden farklıdır. Bundan hareketle bu çalışmada Cumhuriyet Dönemi Türk Eğitim Tarihi Bibliyografyası hazırlanarak araştırmacılara Cumhuriyet'in ilanından sonra Türkiye'deki eğitim alanıyla ilgili yapacakları çalışmalarda bir nebze olsun katkı sağlamak ve zaman kaybını azaltarak daha verimli çalışmalar gerçekleştirmeleri için bu alanda bir kaynakça bilgisi sunulmaya çalışılmıştır. 


\section{YÖNTEM}

Literatür taraması; belirli bir konunun var olan kaynaklar ve belgeler içerisinde detaylı bir şekilde araştırılması ve konuya ait verilerin tespit edilerek sistemli bir biçimde toplanma sürecidir. Karasar’a (2005) göre; araştırma probleminin seçilerek anlaşılması ve araştırmanın tarihsel bir perspektifte oturtulmasına yardımcı olur. Balc1'ya (2005) göre ise; veri toplama ve toplanan verinin öneminin tartışılması, toplanan verilerin problemle ilişkisinin kurulması ve bilginin sınıflandırılması aşamalarından oluşan bir süreçtir.

Bunun yanı sıra literatür taramasının birden farklı amacı vardır. Bourner’e (1996) göre bunlar;

- Literatürdeki boşlukları tanımlamak,

- Tekerleği yeniden icat etmekten kaçınmak,

- Başkalarının ulaştığı yerden alarak daha ileriye götürmek,

- Aynı alanlarda çalışan diğer insanları tanımak,

- Araştırma konusu hakkında bilgi birikimini arttırmak ve etkili çalışmaları tanımak,

- Yapılan çalışmanın entelektüel bağlamını kurarak, diğer projelerle ilişkili bir yere yerleştirmek,

- Zit görünümleri tanımlamak,

- Konuya perspektif kazandırmak,

- Konu hakkındaki önceki çalışmalara erișebildiğinizi göstermek,

- Konuyla ilgili bilgi ve fikirleri tanımlamak,

- Konuya uygun olabilecek yöntemleri belirlemek.

Balcı'ya (2005) göre ise amaçları şunlardır;

- Problemin tanımlanma ve sinırlandırılmasına yardımcı olmak,

- Araştırmayı tarihsel bir perspektife yerleştirmek,

- Çalışmada istenmeyen tekrarları önlemek,

- Uygun yöntem ve ölçülerin seçilmesinde yardımcı olmak,

- Bilgilerin önceki bilgiyle ilişkilendirilmesine yardımcı olmak ve araştırmalara imkân vermek.

Ayrıca literatür taramasını ön kaynak ve detaylı kaynak taraması şeklinde ikiye ayırabiliriz. Ön kaynak taraması; araştırmacının konu hakkında fikir sahibi olmasını ve bu bağlamda konu başlığını tespit etmesini ve yöntemini şekillenmesini sağlayacaktır. Detaylı kaynak taramasında ise; araştırmacının tüm ana ve önemli kaynaklar ile yardımcı kaynaklara 
ulaşmasını ve bu bağlamda çalışmasında nasıl bir yöntem izleyeceğini kararlaştırmasını sağlayacaktır.

Bu çalışmada özellikle 1923 ile 2018 yılları arası Türk Eğitim Tarihini konu alan eserler incelenmiştir. Ayrıca Osmanlı ile Cumhuriyet dönemi eğitim sistemlerini karşılaştıran ve analiz eden eserlere de günümüz eğitim sisteminin anlaşılması bağlamında çalışmada yer verilmiştir.

$\mathrm{Bu}$ araştırmada veriler katalog tarama ve tetkik eser inceleme yöntemleri kullanılarak elde edilmiştir. Katalog taramasında özellikle Türkiye'de yayınlanan tüm eserlerin bir nüshasının bulunduğu başta Millî Kütüphane olmak üzere Ulusal Akademik Ağ ve Bilgi Merkezi Kütüphanesi, Beyazıt Devlet Kütüphanesi, Türk Tarih Kurumu Başkanlığı Kütüphanesi, Ankara Üniversitesi Türk İnkılâp Tarihi Enstitüsü Kütüphanesi, İstanbul Üniversitesi Kütüphanesi, Bilkent Üniversitesi Kütüphanesi, Atatürk Üniversitesi Kütüphanesi, Van Yüzüncü Y1l Üniversitesi Kütüphanesi ve Aysun-Rafet Ataç Kütüphanesi gibi önemli kütüphanelerin toplu katalogları incelenmiştir. Ayrıca elimizde mevcut olan çeşitli müelliflerin eserleri ve süreli yayınlar taranmıştır. Tarama esnasında gözden kaçan bir eser olmamasına önemle dikkat edilmiştir. Ancak buna rağmen gözden kaçan veya bu çalışma esnasında yayına hazırlanan veyahut yayınlanan eserlerin olabileceğini de kabul etmek gerekmektedir. Bununla beraber çalışmaya konu olan eserlerin Türkçe olmasına özen gösterilmiştir. Makale, kitap bölümleri, tezler ve bildiriler bu çalışmanın dışında tutulmuştur.

\section{BULGULAR}

Âdem, M. (2000). Atatürkçü düşünce ışığında eğitim politikamız. İstanbul: Cumhuriyet Kitaplar1.

Ağanoğlu, H. (1949). Köy enstitüleri yolunda. İstanbul: Ahmet Sait Matbaası.

Akbaba, T. (1998). Demokrat Parti ve 27 Mayıs dönemi Türk eğitim. Ankara: Gün Yayıncılık. Akbulut, U. (2003). Tanzimat'tan Cumhuriyet'e eğitim. Ankara: Türkiye Bilimler Akademisi. Akçay, C. (2006). Türk eğitim sistemi. Ankara: Anı Yayıncılık.

Akın, G. (1998). Tonguç’un kır çiçekleri. Ankara: Güldikeni Yayınları.

Akkutay, Ü. (1996). Milli eğitimde yabancı uzman raporları (Atatürk dönemi). Ankara: Kültür ve Eğitim Vakfi.

Akşit, E. E. (2006). Kızların sessizliği (kız enstitülerinin uzun tarihi). İstanbul: İletişim Yayınlar1.

Aktan, M. A. (1999). Köy Enstitüleri’yle canlandırıcı eğitim yolunda. İstanbul: Etki Yayınları. Akyüz, H. (2001). Türk eğitimcileri: I. İstanbul: Milli Eğitim Basımevi. 
Akyüz, Y. (1980). Öğretmen örgütlenmesi (Türkiye, Fransa, İsviçre'de ve uluslararası düzeyde). Ankara: Ankara Üniversitesi Eğitim Fakültesi.

Akyüz, Y. (1982). Türkiye’de öğretmenlik mesleği, çeşitli ülkelerden ögrretmenlik mesleği ve bu konuya verilen önem (1981). Ankara.

Akyüz, Y. (1991). Öğretmen yetiştirme tarihimizde nitelik arayışına iki örnek, eğitimde nitelik geliştirme. İstanbul.

Akyüz, Y. (1996). Ülkemizde üniversite eğitiminin tarihsel gelişimi, üniversite e ğitimi. Ankara.

Akyüz, Y. (2012). Türkiye'de ögretmenlerin toplumsal değişmedeki etkileri (1839 - 1950). Ankara: Pegem Akademi Yayınları.

Akyüz, Y. (2013). Türk eğitim tarihi M.Ö. 1000 - M.S. 2013. Ankara: Pegem Akademi Yayınları.

Alıcıgüzel, İ. (1979). İlk ve orta dereceli okullarda öğretim. İstanbul: İnkılap ve Aka Kitapevleri.

Altunya, N. (1998). Türkiye’de öğretmen örgütlenmesi (1908-1998). Ankara: Ürün Yayınları. Altunya, N. (2000). Köy enstitü sisteminin düşünsel temelleri. Ankara.

Altunya, N. (2005). Köy enstitü sistemine toplu bir bakış. İstanbul: Kelebek Matbaası.

Altunya, N. (2006). Gazi orta öğretmen okulu ve eğitim enstitüsü (1926-1980). Ankara: Gazi Üniversitesi Yayını.

Altunya, N. (2009). Milli ĕgitimde Mustafa Necati dönemi. İstanbul: Başarı Yayınevi.

Altunya, N. (2018). Türkiye’de ögrretmen yetiştirme deneyimi (1848-2018). İstanbul: Öğretmen Dünyası Yayınları.

Antel, S. C. (1939). Maarifimiz ve meseleleri. İstanbul: Remzi Kitabevi.

Apaydın, T. (1990). Köy enstitüsü yılları. İstanbul: Çağdaş Yayınları.

Apaydın, T. (1995). Bilgiden bilince eğitim. Ankara: EĞİT-DER Yayınları.

Arabacı, C. (1991). Milli mücadele dönemi Konya öğretmenleri. Konya: Damla Matbaacılık.

Arıbaş, S. (1992). Mehmet Akif'in eğitim üzerine düşünceleri. İstanbul: Medeniyet Yayınları.

Arıkan, C. (2012). Neden, köy enstitüleri?. İstanbul: Markiz Yayınevi.

Arman, H. (1969). Piramidin tabanı, köy enstitüleri ve Tonguç-anılar 1. Ankara: İş Matbaacılık ve Ticaret.

Arman, H. (1971). Piramidin tabanı, köy enstitüleri ve Tonguç-neler dediler 2. Ankara: İş Matbaacılik ve Ticaret.

Arman, H. (1990). Piramidin tabanı, köy enstitüleri ile başlatılan büyük imece. İstanbul: Arkın Yayınevi. 
Arslan, A. (1995). Darülfünun’dan üniversite’ye. İstanbul: Kitabevi Yayınları.

Arslan, M. M. (1992). Türkiye’de yaygın ĕgitim. Ankara: Erek Ofset.

Arslanoğlu, İ. (1996). Kastamonu ögretmen okulları (1884-1977). Ankara: Milli Eğitim Yayınları.

Arslanoğlu, İ. (1997). Türk eğitim sistemi. Ankara.

Şenalp, L. (Haz). (1984). Atatürk kaynakçası (C. 2). Ankara: Türk Tarih Kurumu Basımevi.

Durusoy, M. O. ve Gökman, M. M. (1957). Atatürk ve devrimleri bibliyografyası. Ankara: Türk Tarih Kurumu Basımevi.

Atatürk, M. K. (1994). Nutuk (1919-1927). Z. Korkmaz (Haz.), Ankara: Atatürk Kültür, Dil ve Tarih Yüksek Kurumu Atatürk Araştırma Merkezi.

Atatürk, M. K. (1982). Nutuk (C. I-II-III). İstanbul: Milli Eğitim Basımevi.

Atatürk'ün söylev ve demeçleri I (1961). Ankara: Atatürk Araştırma Merkezi.

Atatürk'ün söylev ve demeçleri II (1959). Ankara: Atatürk Araştırma Merkezi.

Atatürk’ün söylev ve demeçleri III (1961). Ankara: Atatürk Araştırma Merkezi.

Ataünal, A. ve Özalp, R. (1977). Türk milli eğitim sisteminde düzenleme teşkilatı. İstanbul: Milli Eğitim Basımevi.

Ataünal, A. (1993). Cumhuriyet döneminde yüksekögretimdeki gelişmeler. Ankara: Milli Eğitim Basımevi.

Ataünal, A. (1997). Türkiye’de ilkokul ögrretmeni yetiştirme sorunu (1923-1994) ve ABD, Ingiltere, Fransa ve Almanya'daki çă̆daş uygulama ve ĕgilimler. Ankara: Milli Eğitim Basımevi.

Avşaroğlu, A. (1970). Eğitim sorunlarımız. Ankara: Ege Matbaası.

Ayas, N. (1948). Türkiye Cumhuriyeti milli eğitimi, kuruluşlar ve tarihçeler. Ankara: Milli Eğitim Basımevi.

Aydın, İ., Paksoy, A., vd. (1988). Ankara ilinin Cumhuriyet öncesi ve Cumhuriyet dönemi eğitimi. Ü. Sarıaslan (Haz.), Ankara: Ankara Valiliği Milli Eğitim Müdürlüğü Yayınları.

Aydın, İ. (1999). Dünden bugüne öğretenler (1065-2005). Ankara: Eğitim Sen Yayınları.

Aydoğan, M. (1997). Köy enstitüleri-amaçlar-ilkeler-uygulamalar. Ankara: KEÇEV.

Aydoğan, M. (2006). Köy eğitim sistemi-köy enstitüleri. Ankara: Aydan Yayıncılık.

Aynî, M. A. (1927). Darülfünun tarihi. İstanbul.

Aytaç, K. (1984). Gazi Mustafa Kemal Atatürk’ün eğitim politikası üzerine konuşmaları. Ankara: Ankara Üniversitesi Basımevi.

Balkır, S. E. (1968). Eski bir ögrretmenin anıları: 1908-1940. İstanbul: Ar1 Kitabevi. 
Baloğlu, Z. (1990). Türkiye’de eğitim. İstanbul: TÜSİAD Yayınları.

Baltacioğlu, İ. H. (1927). Talim ve terbiyede inkılâp. İstanbul: Kanaat Kütüphanesi.

Baltacioğlu, İ. H. (1932). İçtimai mektep nazariyesi ve prensipleri. İstanbul.

Baltacioğlu, İ. H. (1933). Mürebbilere. İstanbul.

Baltacıoğlu, İ. H. (1938). Toplu tedris. İstanbul: Sebat Basımevi.

Baltacıŏlu, İ. H. (1942). İçtimai mektep. Ankara: Maarif Matbaası.

Baltacioğlu, İ. H. (1950). Halkın evi. Ankara.

Baltacioğlu, İ. H. (1964). Pedagojide ihtilal. İstanbul.

Başar, E. (1999). Milli Ĕgitim Bakanlarının ĕgitim faaliyetleri (1960-1971). İstanbul: Milli Eğitim Yayınları.

Başar, E. (2004). Milli Ĕgitim Bakanlarının eğitim faaliyetleri (1920-1960). İstanbul: Milli Eğitim Yayınları.

Başaran, A. R. (1987). Üniversite tarihi, üniversiteler ve fakültelerle ilgili kanun ve yönetmelikler. İstanbul.

Başaran, İ. E. (1994). Türkiye eğitim sistemi. Ankara.

Başaran, M. (1974). Tonguç yolu; köy enstitüleri, devrimci eğitim. İstanbul: Varlık Yayınları.

Başaran, M. (1990). Özgürleşme eylemi, köy enstitüleri. İstanbul: Çağdaş Yayınları.

Başaran, M. (1990). Sabahattin Eyüboğlu ve köy enstitüleri. İstanbul: Cem Yayınevi.

Başaran, M. (1999). Devrimci eğitim köy enstitüleri. İstanbul: Papirüs Yayınları.

Başgöz, İ., Wilson, H. E. (1968). Türkiye Cumhuriyetinde eğitim ve Atatürk. Ankara: Dost Yayınlar1.

Başgöz, İ. (1995). Türkiye’nin eğitim çıkmazı ve Atatürk. Ankara: Kültür Bakanlığı Yayınları.

Batır, E. (2010). Geleneksel ĕgitimden çă̆daş ĕgitime. İstanbul: Elif Kitabevi.

Bayır, F. O. (1971). Köyün gücü. Ankara: Ulusal Basımevi.

Baykurt, F. (2016). Unutulmaz köy enstitüleri. İstanbul: Literatür Yayıncılık.

Baymur, F. (1939). Illk okuma ve yazma ögretimi. İstanbul.

Berkes, N. (1978). Türkiye’de çağdaşlaşma. İstanbul: Doğu Batı Yayınları.

Bilasa, P. (2013). Türkiye’de ilköğretim tarihsel gelişimi (1970-2010). Ankara: Pegem Akademi.

Bilgen, H. N. (1994). Çă̆daş ve demokratik eğitim. Ankara.

Bilgili, A. S., Arıbaş, S. ve Köçer, M. (2011). Türk eğitim tarihi. İstanbul: Lisans Yayıncılık.

Bilgiseven, Â. K. (1986). Milli eğitim stratejimiz nasıl olmalıdır?. İstanbul: Türk Dünyası Araştırmaları Vakfı Yayınları. 
Bilim, C. Y. (2002). Türkiye'de çağdaş eğitim tarihi. Eskişehir: Anadolu Üniversitesi Edebiyat Fakültesi Yayınları.

Binbaşığlu, C. (1982). Eğitim düşüncesi tarihi. Ankara: Binbaşığlu Yayınevi.

Binbaşığlu, C. (1993). Çağdaş eğitim ve köy enstitüleri, tarihsel bir çerçeve. İzmir: Dikili Belediyesi Yayınları.

Binbaşığlu, C. (1995). Türkiye’de eğitim bilimleri tarihi. İstanbul: Milli Eğitim Basımevi.

Binbaşıŏlu, C. (1999). Cumhuriyet dönemi eğitim bilimleri tarihi. Ankara: Tekışık Yayınları.

Binbaşığlu, C. (2005). Türk eğitim düşüncesi tarihi. Ankara: Anı Yayıncılık.

Binbaşığlu, C. (2014). Türk eğitim tarihi. Ankara: Anı Yayıncılık.

Bingöl, V. (1979). Atatürk’ün milli eğitimimizle ilgili düşünce ve buyrukları. Ankara.

Birleşmiş Milletler Türk Derneği (1997). Hasan Ali Yücel'e armağan. Ankara: Birleşmiş Milletler Türk Derneği Yayınları.

Bolay, S. H., İsen, M., Türköne, M., Cafoğlu, Z., Erdoğan, İ., Kabasakal, Ö. Ve Yasa, A. (1996). Türk ĕgitim sistemi. Ankara: Alternatif Perspektif.

Boydak, H. A. (2011). Ĕ̌gitimde ăgalıktan demokrasiye. İstanbul: Beyaz Yayınları.

Bursalığlu, Z. (1981). Atatürk devrimleri ve eğitim sempozyumu. Ankara: Ankara Üniversitesi Eğitim Fakültesi Yayınları.

Candoğan, G. (1948). Köy enstitüleri üzerine düşünceler. İstanbul.

Candoğan, G. (1990). İvriz köy enstitüsündeki ögrrencilik yıllarım. Konya.

Candoğan, G. (1991). Tonguç’un köy öğretmeni. Konya.

Candoğan, G. (1999). Köy enstitüleri sistemi. Konya.

Celkan, H. Y. (1990). Ziya Gökalp’in eğitim sosyolojisi. İstanbul.

Ceylan, E. (2014). Türk eğitim tarihi kronolojisi 1299-1997. Edirne: Ulusal Bellek Yayınları. CHP 1945 yılında halkevleri ve halkodaları (1946). Ankara.

CHP halkevleri çalışma talimatnamesi (1940). Ankara.

CHP halkevleri talimatnamesi (1934). Ankara.

CHP halkevleri ve halkodalarının 14'üncü yıl dönümü (1946). Ankara.

CHP halkevleri ve halkodalarının 1940 Çalışmaları (1941). Ankara.

CHP halkodaları talimatnamesi (1939). Ankara.

CHP XVI. yıldönümünde halkevleri ve halkodaları (1948). Ankara.

Cicioğlu, H. (1982). Türkiye Cumhuriyetinde ilk ve orta ögretim (tarihi gelişimi). Ankara: Ankara Üniversitesi Eğitim Bilimleri Fakültesi Yayınları.

Cimi, M. (2001). Tonguç baba (ülkeyi kucaklayan adam). Ankara: Kültür Bakanlığı. 
Coşkun, A. (2010). Hasan Ali Yücel: aydınlanma devrimcisi. İstanbul: Cumhuriyet Kitapları.

Coşkun, H. (2006). Hasanoğlan-Elmadă̆: Eğitim açısından bir çevre incelemesi. İstanbul: BOSCH Sanayi ve Ticaret A.Ş.

Çağlar, B. K. (1968). Bugünün diliyle Atatürk’ün söylevleri. Ankara: Ankara Üniversitesi Basımevi.

Çevik, İ. (2001). 21. yüzyılda Türk milli eğitimi. Ankara: Kamu-Sen.

Çıkar, M. (1998). Hasan Ali Yücel ve Türk kültür reformu. İstanbul: Türkiye İş Bankası Kültür Yayınlar1.

D.P.T. (1988). Beş ylllık planlı dönemde temel eğitim ve lise seviyeli eğitimin yeniden düzenlenmesiyle ilgili politikalar ve uygulamaları. Ankara: Milli Eğitim Basımevi.

D.P.T. (1970). Yükseköğretim araştırması. Ankara: DPT Yayınları.

D.P.T. (1976). Planlı dönemde yükseköğretim. Ankara: DPT Yayınları.

D.P.T. (1971). Yükseköğretim özel ihtisas komisyonu raporu. Ankara: DTP Yayınları.

Dağlar, A. L. (1989). Düziçi köy enstitüsü ve sonrası kimi anılarım. Ankara.

Demirtaş, A. (1993). Çă̆daş eğitim ve köy enstitüleri. İzmir: Dikili Belediyesi Yayınları.

Dewey, J. (1930). Mektep ve cemiyet. B. Avni (Çev.), İstanbul.

Dewey, J. (1939). Türkiye maarifi hakkında rapor (1924). İstanbul: Maarif Vekilliği Devlet Basımevi.

Dilaver, H. (1997). Hasanoğlan'dan kuruluşundan günümüze öğretmen yetiştiren kurumlar. Ankara.

Dilaver, H. (1994). Türkiye’de öğretmen yetiştirme ve istihdam şartları. İstanbul.

Doğan, İ. (2010). Türk eğitim tarihinin ana evreleri kurumlar, kişiler ve söylemler. Ankara: Nobel Yayın Dağıtım.

Doğaner, Y. (Ed.). (2006). Türk eğitim sisteminde Atatürkçülük ve Türkiye Cumhuriyeti tarihi ögretimi. Ankara: Hacettepe Üniversitesi Atatürk İlkeleri ve İnkılâp Tarihi Enstitüsü Yayınlar1.

Dölen, E. (2010). Cumhuriyet döneminde İstanbul darülfünunu (1922-1933): Türkiye üniversite tarihi 2. İstanbul: İstanbul Bilgi Üniversitesi Yayınları.

Dölen, E. (2010). Darülfünun'dan üniversiteye geçiş: Türkiye üniversite tarihi 3. İstanbul: İstanbul Bilgi Üniversitesi Yayınları.

Dölen, E. (2010). İstanbul üniversitesi (1933-1946): Türkiye üniversite tarihi 4. İstanbul: İstanbul Bilgi Üniversitesi Yayınları. 
Dölen, E. (2010). Özerk üniversite dönemi, (1946-1981): Türkiye üniversite tarihi 5. İstanbul: İstanbul Bilgi Üniversitesi Yayınları.

Duman, T. (1991). Cumhuriyeti Dönemi’nde orta dereceli okul öğretmenlerini yetiştirilmesi. Ankara.

Duman, T. (1991). Türkiye’de ortaöğretime ögretmen yetiştirme (tarihi gelişimi). Ankara: Milli Eğitim Basımevi.

Durak, M. (2000). Her yönüyle Tahsin Yücel. İstanbul: Multilingual Yabancı Dil Yayınları.

Emiralioğlu, M. (1967). Hasan Ali Yücel. Ankara: Emel Yayınları.

Er, H. (1999). Osmanlı Devletinde çağdaşlaşma ve eğitim. İstanbul: Rağbet Yayınları.

Erçelebi, H. (1993). Köy enstitülerini çağdaş eğitim yönetimine katkıları. İzmir: Dikili Belediyesi Yayınlar1.

Erdal, İ. (2013). Halkevlerinin kuruluşu, yapısı ve Yozgat halkevleri (1932-1951). Ankara: Siyasal Kitapevi.

Erdem, T. ve Erez, İ. S. (1963). Kuruluşlarının yıldönümünde halkevleri. İstanbul.

Ergin, O. (1977). Türkiye maarif tarihi (C. I-II-III-IV-V). İstanbul.

Erginöz, O. N. (1943). Köy eğitiminde yaşanmış realiteler. Bursa.

Ergün, M. (1992). Eğitim ve toplum. Ankara: Ocak Yayınları.

Ergün, M. (1997). Atatürk devri Türk eğitimi. Ankara: Ocak Yayınları.

Eşme, İ. (2001). Yüksek öğretmen okulları. İstanbul: Bilgi-Başarı Yayınevi.

Evren, N. (1997). Poyraz köy’den köy enstitülerine. Ankara: Güldikeni Yayınları.

Evren, N. (1997). Rauf İnan köy enstitüleri ve bir ömrün tanıklı̆̆ı. Ankara.

Evren, N. (1998). Köy enstitüleri neydi. Ne Değildi, Ankara.

Evren, N. (1999). Osmanlı eğitim sisteminden Cumhuriyet'e. Ankara.

Eyüboğlu, S. (1979). Köy enstitüleri üzerine. İstanbul: Cem Yayınevi.

Fırtına, B. (1999). Aydınlanma savaşımı. İstanbul.

Fırtına, B. (2006). Bilge İnsan Sitkı Akkay-Savaştepe köy enstitüsü kurucu müdürü. İzmir: Yeni Kuşak Köy Enstitüsü Derneği Yayınları.

F1rtına, B. (2003). Köy enstitülerinde usta öğrenciler. İzmir.

Gazalcı, M. (1998). Aydınlık için laik eğitim. Ankara.

Gazalcı, M. (2007). Kuşatılan Cumhuriyet eğitimi (2002-2007). Ankara: Eğit-Der Yayınları.

Gazalcı, M. (2016). Köy enstitüleri sistemi mezunları üzerine bir araştırma. Ankara: Bilgi Yayınevi.

Gedikli, T. (1998). Aydınlanma ışıkları köy enstitüleri. Sivas. 
Gedikoğlu, Ş. (1949). Niçin? Eğitmen kursları köy enstitüleri. Ankara: İdeal Basım ve Cilt Evi. Gedikoğlu, Ş. (1971). Evreleri, getirdikleri ve yankılarıyla köy enstitüleri. Ankara: İş Matbaacilık Tic.

Gedikoğlu, Ş. (1978). Kemalist eğitim ilkeleri ve uygulamalar. İstanbul: Çağdaş Yayınları.

Geray, C. (1978). Halk eğitimi. Ankara: Ankara Üniversitesi Eğitim Fakültesi Yayınları.

Göğer, Ö. (2013). Cavit Binbaşıŏglu’nun Türk eğitim ve kültür hayatına hizmetleri. Ankara: Anı Yayıncilık.

Gök, F. (Ed.). (1999). 75 yılda eğitim. İstanbul: Tarih Vakfi Yayınları.

Gökalp, Z. (1964). Milli terbiye ve maarif meselesi. Ankara: Diyarbakır'1 Tanıtma ve Turizm Derneği Yayınlar.

Güleç, İ. (2015). Metinlerde eğitim tarihi; ders notları. Sakarya: Sakarya Üniversitesi.

Güler, A. (1994). Türkiye’de üniversite reformları. Ankara: Adım Yayıncılık.

Gündüz, M. (Ed.). (2018). Kronolojik ve tematik Türk eğitim tarihi. İstanbul: İdeal ve Kültür Yayınc1lık.

Gündüzalp, F. (1951). Öğretmen meslek kitapları kılavuzu 1939-1948 (C. II). Ankara: Milli Eğitim Basımevi.

Gündüzalp, F. (1959). Teşkilat ve idare. İstanbul: Milli Eğitim Basımevi.

Güneri, M. (2004). Hasanoğlan köy enstitüsü kurulurken 1941-1951. D. Güneri (Ed.), İstanbul: Türkiye Ekonomik ve Toplumsal Tarih Vakfi.

Güneş, M., ve Güneş, H. (2005). Türkiye'de eğitim politikalarl ve sivil toplum. Ankara: Anı Yayıncilik.

Güngör, N. (1991). Kültür-eğitim-dil üzerine görüşleri ile Ziyaeddin Fahri Fındıkoğlu. Ankara: Kültür Bakanlığı Yayınları.

Gür, B., ve Çelik, Z. (2009). Türkiye'de milli eğitim sistemi yapısal sorunlar ve öneriler. İstanbul: Siyaset, Ekonomi ve Toplumsal Araştırmalar Vakfı Yayınları.

Gürüz, K. (2008). Yirmi birinci yüzyılın başında Türk milli eğitim sistemi. İstanbul: Türkiye İş Bankası Kültür Yayınları.

Güven, İ. (2000). Türkiye’de devlet, eğitim ve ideoloji. Ankara: Siyasal Kitabevi Yayınları.

Güven, İ. (2010). Türk eğitim tarihi. Ankara: Naturel Yayıncılık.

Güvenç, B. (2005). Cumhuriyet döneminde eğitim. Ankara: Türk Bilimler Akademisi.

Güz, N. (1993). Halkevleri dergileri üzerine bir inceleme. Ankara: Teksir Yayınları.

Hacaloğlu, Y. (1962). Neden köy enstitüleri değil.... İstanbul: Toprak Dergisi Yayını.

Hatipoğlu, M. T. (2000). Türkiye üniversite tarihi. Ankara: Selvi Yayınevi. 
Hatipoğlu, M. T. (2015). Üniversite üzerine dertleşi; Medrese, mektep, darülfünun, üniversite, YÖK. Ankara: Selvi Yayınları.

Hesapçığlu, M. (1984). Türkiye’de insan gücü ve eğitim planlamast. Ankara: Ankara Üniversitesi Eğitim Bilimleri Fakültesi Yayınları.

Hesapçıŏglu, M. ve Durmuş, A. (Ed.). (2006). Türkiye’de eğitim bilimleri; bir bilanço denemesi. Ankara: Nobel Yayın Dağıtım.

İlker, H. (2012). Suçumuz köy enstitülü olmak: Düzmece bir davanın anatomisi. İstanbul: E Yayınları.

İnan, M. R. (1975). Atatürk’ün devraldığg ĕgitim-öğretim durumu ve kurumları. Ankara: Türk Tarih Kurumu Basımevi.

İnan, M. R. (1976). Bir üstün adam (Rüsstü Uzel). Ankara.

İnan, M. R. (1977). 50. yılında Türkiye Cumhuriyeti ve eğitim. Ankara: Türk Tarih Kurumu Basımevi.

İnan, M. R. (1980). Mustafa Necati. Ankara: Türkiye İş Bankası Yayınları.

İnan, M. R. (1988). Köy enstitüleri ve sonrası. Ankara: Öğretmen Yayınları.

İnan, M. R. (1989). Ĕgitim alanında Atatürk devrimi. Ankara.

İpşiroğlu, Z. (1997). Eğitimde yeni arayışlar: Sorunlar, seçenekler, öneriler. İstanbul: Adam Yayınlar1.

İskit, S. R. (1939). Türkiye’de neşriyat hareketleri. İstanbul: Devlet Basımevi.

Kafadar, O. (1997). Türk eğitim düşüncesinde batılılaşma. Ankara: Vadi Yayınları.

Kanar, H. (1991). Köy enstitüleri eğitimde atılım. Ankara: Selvi Yayınları.

Kanat, H. F. (1930). Terbiye ve tedris tarihi. İstanbul: Devlet Matbaas1.

Kanat, H. F. (1942). Milliyet ideali ve topyekûn milli terbiye. Ankara: Çankaya Matbaası.

Kansu, N. A. (1930/1932). Türkiye maarif tarihi (C. I-II). İstanbul: Muallim Ahmet Halit Kitabhanesi.

Kaplan, İ. (2005). Türkiye’de milli eğitim ideolojisi. İstanbul: İletişim Yayınları.

Kaplan, M. (2002). Aydınlanma devrimi ve köy enstitüleri. Ankara: Kültür Bakanlığı Yayınları.

Karakütük, K. (2001). Demokratik laik ĕgitim: Çăgdaş toplum olmanın yolu. Ankara: Anı Yayınc1lik.

Kırpık, G., Ünal, U., Işık, H., Demirtaş, B., Tokdemir, M. A., Birbudak, T. S. ve Akyol, H. (2014). Türk eğitim tarihi. Ankara: Otorite Yayınları.

Kısakürek, M. A. (1976). Üniversitelerimizde yenileşme "programlar ve ögrretim açısından”. Ankara: Ankara Üniversitesi Eğitim Fakültesi Yayınları. 
Kirby, F. (2010). Türkiye'de köy enstitüleri. N. Berkes (Çev.), İstanbul: Tarihçi Kitabevi.

Kocabaş, K. (Ed.). (2011). Hasan-Ali Yücel. Ankara: Kültür ve Turizm Bakanlığı Yayınları.

Kocabaş, K. (Ed.). (2010). Ortaklar köy enstitüsünden ortaklar ilk öğretmen okuluna. İzmir: Yeni Kuşak Köy Enstitüleri Derneği Yayınları.

Kocatürk, U. (1999). Atatürk’ün fikir ve düşünceleri. Ankara: Atatürk Kültür, Dil ve Tarih Yüksek Kurumu Atatürk Araştırma Merkezi Yayınları.

Koç, N. (1996). Üniversite eğitimimiz. Ankara: Ankara Üniversitesi Eğitim Bilimleri Enstitüsü.

Koç, N. (2006). Laik ĕgitimden şeriatçı eğitime: Ulusal eğitimde çöküşs süreci. İstanbul: Berfin Yayınları.

Koçer, H. A. (1967). Türkiye’de öğretmen yetiştirme problemi. Ankara: Yargıçoğlu Matbaası.

Koçer, H. A. (1980). Eğitim tarihi I. Ankara: Ankara Üniversitesi Eğitim Bilimleri Fakültesi Yayınları.

Koçer, H. A. (1991). Türkiye’de modern eğitimin doğuşu ve gelişimi (1773-1923). İstanbul: Milli Eğitim Basımevi.

Koçer, H. A. (1992). Eğitim sorunları üzerine düşünceler. İstanbul.

Kodamanoğlu, M. N. (1964). Türkiye’de eğitim (1923-1960). Ankara: Milli Eğitim Basımevi.

Kolçak, S. (1946). İlköğretimin temel davaları. İstanbul: Kanaat Kitabevi.

Konukman, E. (1989). Topluluktan millete. İstanbul: Belge Yayınları.

Korkut, H. (2002). Sorgulanan yükseköğretim. Ankara: An1 Yayıncılık.

Koryürek, S. ve Yılmaz, H. T. (1997). Öğrenci gözüyle köy enstitüleri. İstanbul: Görkem Yayınları.

Köstüklü, N. (2003). Kâzım Karabekir ve eğitim. Konya: Çizgi Kitabevi.

Köymen, N. (1952). Demokrasiyi kurtaracak halk eğitimdir. İstanbul: Türkiye Basımevi.

Kurtuluş, Y. (2001). Köy enstitülerinde sanat eğitimi ve Tonguç. Ankara: Güldikeni Yayınları. Kut, D. (2003). Demet'li yıllar Tonguç'la Yücel'le. Ankara: Güldikeni Yayınları.

Küçükcan, T. (2009). Türkiye’de yükseköğretim: Karşılaştırmalı bir analiz. Ankara: Seta Yayınları.

Levent, A. S. (1940). Maarifimiz ve milli terbiyemiz. İstanbul.

M.E.B. (1946). Cumhurbaşkanları, başbakanlar ve milli eğitim bakanlarının milli eğitim ile ilgili söylev ve demeçleri (C. 1). Ankara: Milli Eğitim Basımevi.

M.E.B. (1952). Öğretmen okulları ve köy enstitüleri programı (taslak). Ankara: Milli Eğitim Basımevi. 
M.E.B. (1970). Fırsat ve imkân eşitliği bakımından Türk milli eğitimindeki gelişmeler (195458). Ankara: Milli Eğitim Basımevi.

M.E.B. (1973). Cumhuriyetin 50. yılında milli eğitimimiz. İstanbul: Milli Eğitim Bakanlığ1 Devlet Kitapları Yayınları.

M.E.B. (1983). Cumhuriyet döneminde eğitim. Ankara: Milli Eğitim Basımevi.

M.E.B. (1987). Cumhuriyet dönemi eğitimcileri (40 eğitimci hakkında incelemeler). Ankara: Milli Eğitim Basımevi.

M.E.B. (1988). Cumhuriyet döneminde Türk milli eğitim sisteminde gelişmeler (1923-1988). Ankara: Milli Eğitim Basımevi.

M.E.B. (1998). Cumhuriyetin 75. yılında yükseköğretim. Ankara: Milli Eğitim Basımevi.

M.E.B. (1999). Çăğdaş ögretmen profili. Ankara: MEB-EARGE Yayınları.

M.E.B. (2000). 2001 yılı başında milli ĕ̆itim. Ankara: Milli Eğitim Basımevi.

M.E.B. (2006). Milli eğitim şuraları (1921-2006). Ankara: Milli Eğitim Basımevi.

Madaralı, F. (1980). Tonguç ışı̆̆ı. İstanbul: Yaylacık Matbaası.

Makal, M. (2015). Köy enstitüleri ve ötesi. İstanbul: Literatür Yayınc1lık.

Mustafa N. (1928). Illk mektep muallimleriyle mesleki bir hasbihal. Ankara: Türk Ocaklar1 Merkez Heyeti Matbaas1.

Mümtaz, T. (1964). Maarifimizin ana davaları ve bazı hal çareleri. İstanbul: Bedir Yayınları.

Oğuzkan, F. (Ed.). (1981). Türkiye’de ortaöğretim. İstanbul: Boğaziçi Yayınları.

Okçabol, R. (2005). Öğretmen yetiştirme sistemimiz. Ankara: Ütopya Yayınevi.

Okudan, İ. (2006). Milli Eğitim Bakanı Tevfik Illeri. Ankara: Türk Ocakları Ankara Şubesi Yayınları.

Okurer, C. (1965). Ana hatlarıyla milli eğitim politikamız. Ankara.

Öklem, N. (1973). Atatürk döneminde darülfünun reformu. Bornova: Ege Üniversitesi Yayınlar1.

Önder, M. (2011). Türk ĕgitim tarihi. Ankara: Sözkesen Matbaacılık.

Öner, S. (1979). Köy enstitülerinden eğitim enstitülerine. İstanbul.

Öymen, H. R. (1969). Doğulu ve Batılı yönüyle ĕgitim tarihi. Ankara.

Öymen, H. R. (1969). Türkiye’nin ana eğitim problemleri: Devrimler ve reformlar açısından I. Ankara: Ankara Üniversitesi Dil Tarih ve Coğrafya Fakültesi Yayınları.

Öymen, H. R. (1988). Cumhuriyet eğitimine geçişte Atatürk' ün etkisi. Ankara: Türk Tarih Kurumu Basimevi. 
Öymen, H. R. (1983). Türkiye Cumhuriyeti’nin eğitim devrimi: 1923-1938. Ankara: Türk Tarih Kurumu Basimevi.

Özalp, R. ve Ataünal, A. (1977). Türk milli eğitim sisteminde düzenleme teşkilatı. İstanbul: Milli Eğitim Bakanlığg Yayınları.

Özbaran, S. (1988). Tarih eğitimi ve tarihte öteki sorunu. İstanbul: Tarih Vakfı Yurt Yayınları. Özbek, N. (2000). Türkiye’deki yabancıların öğrenim ve ögretim özgürlüğü. Ankara.

Özer, M. (2001). Ívriz köy enstitüsü. İzmir.

Özgedik, M. (2014). Türk eğitim tarihi. İstanbul: Ülke Yayın Haber.

Özgen, B. (1991). Köy enstitülerinde uygulanan eğitim-ögrretim ilke ve yöntemleri. İzmir.

Özgen, B. (1993). Çă̆daş eğitim ve köy enstitüleri. İzmir: Dikili Belediyesi.

Özkan, S. (2014). Türk eğitim tarihi. Ankara: Nobel Yayınları.

Özkucur, A. (1985). Köy enstitüleri destanı. Ankara: Öğretmen Yayınları.

Özkucur, A. (1990). Hasanoğlan yüksek köy enstitüsü. Ankara: Selvi Yayınları.

Özodaşık, M. (1999). Cumhuriyet dönemi yeni bir nesil yetiştirme çalışmaları (1923-1950). Konya: Çizgi Kitabevi.

Öztürk, C. (1996). Atatürk devri ögrretmen yetiştirme politikası. Ankara: Türk Tarih Kurumu Basimevi.

Öztürk, C. (1998). Türkiye’de dünden bugüne ögrretmen yetiştiren kurumlar. İstanbul: Marmara Üniversitesi Eğitim Fakültesi.

Öztürk, S. (2007). Eğitim Mühendisi Fahamettin Akıngüç kitabı. İstanbul: İş Bankası Kültür Yayınları.

Öztürkmen, N. (1968). Kalkınan Türkiye’de eğitim ve gençlik. Ankara.

Palazoğlu, A. B. (1990). Atatürk ve eğitim. Ankara: Milli Eğitim Bakanlığı Yayınları.

Palazoğlu, A. B. (1991). Başöğretmen Atatürk: I (1919-1928). Ankara: T.C. Milli Eğitim Bakanlığg Eğitim Araçları ve Donatım Dairesi Başkanlığı Yayını.

Palazoğlu, A. B. (1999). Atatürk’ün eğitimle ilgili düşünceleri. Ankara: T.C Milli Eğitim Bakanlığı Eğitim Araçları ve Donatım Dairesi Başkanlığı Yayını.

Palazoğlu, A. B. (1999). Atatürk’ün okul gezileri. Ankara: Milli Eğitim Yayınları.

Pazar, M. (2001). Demokratik eğitimde bir anıt kurum: Köy enstitüleri. Ankara: Güldikeni Yayınları.

Polvan, N. (1952). Türkiye’de yabancı öğretim (C. 1). İstanbul: Milli Eğitim Basımevi.

Sakaoğlu, N. (1992). Cumhuriyet dönemi eğitim tarihi. İstanbul: İletişim Yayını. 
Sakaoğlu, N. (2003). Osmanlıdan günümüze eğitim tarihi. İstanbul: İstanbul Bilgi Üniversitesi Yayınları.

Saral, M. (2002). Karartılan aydınlık köy enstitüleri Düziçi köy enstitüsü. Hatay.

Sarıhan, Z. (2009). 1921 Maarif kongresi. Ankara: Milli Eğitim Basımevi.

Sarığlu, M. (2012). Türk ĕgitim tarihinden esintiler, Kocaeli: Umuttepe Yayınları.

Semerci, B. (1989). Türkiye’de ileri atılımlar ve köy enstitüleri. İstanbul: Özgür Yayın Dağıtım.

Sezer, A. (2000). Atatürk döneminde yabancı okullar (1923-1938). İstanbul: Türk Tarih Kurumu Basımevi.

Sorguç, B. (1982). 1920’den 1981'e milli eğitim bakanlı̆̆g. İstanbul: Milli Eğitim Basımevi.

Sorguç, B. (1995). Cumhuriyetin 70. yılında milli eğitim. Ankara.

Sorguç, B. ve Cirıtlı, H. (Ed.). (1987). Cumhuriyet dönemi eğitimcileri. Ankara: UNESCO Türkiye Milli Komisyonu Yayını.

Soysal, M. E. (1940). Kızılçullu köy enstitüsü sistemi 1. Ankara.

Soysal, M. E. (1943). Klzılçullu köy enstitüsü sistemi 2. Ankara.

Soysal, M. E. (1943). Köy enstitüleri’nin tarihçesi. Bursa: Yeni Basımevi.

Soysal, M. E. (1945). İlköğretim olayları ve köy enstitüleri. Bursa: Uygun Basımevi.

Sönmez, C. (2004). Atatürk'ün yetiştirmesi ve öğretmenleri. Ankara.

Sönmez, Ş. (2000). Eğitim ve siyasette Hasan Ali Yücel. Ankara: Kültür Bakanlığı Yayınları.

Söylemez, M. (1997). Problem ve çözümleriyle eğitimimiz. İzmir: Çağlayan Yayınları.

Şahhüseyinoğlu, H. N. (2005). Akçadağ köy enstitüsü ve Şerif Tekben. Ankara: Ürün Yayınları.

Şanal M. (2007). Kayseri halkevi ve faaliyetleri (1932-1950). Kayseri: Kayseri Büyükşehir Belediyesi Yayınları.

Şengör, A. M. C. (2005). Hasan Ali Yücel ve Türk aydınlanması. Ankara: TÜBİTAK.

Tanilli, S. (2004). Nasıl bir ĕgitim istiyoruz?. İstanbul: Adam Yayınları.

Taşdemirci, E. (1992). Belgelerle 1933 üniversite reformunda yabancı bilim adamları. Ankara: Bizim Büro Basımevi.

Taşdemirci, E. (2010). Türk eğitim tarihi. Ankara: Gündüz Eğitim ve Yayıncılık.

Tekben, Ş. (1947). Canlandırılacak köy yolunda. Malatya: Akçada Köy Enstitüsü Basımevi.

Tekben, Ş. (1962). Neden köy enstitüleri?. İstanbul: Türkiye Milli Gençlik Teşkilatı Yayını.

Tekeli, İ. (2010). Tarihsel bağlamı içinde Türkiye'de yükseköğretimin ve YÖK'ün tarihi. İstanbul: Türk Vakfı Yurt Yayınları.

Tekeli, İ. (2011). Türkiye için eğitim yazıları. İstanbul: Tarih Vakfı Yurt Yayınları. 
Tekin, M. (2006). Geçmişten günümüze Türk eğitim kurumları. Adıyaman: Eğitim Umut Yayınları.

Tezcan, M. (1992). Atatürk ve eğitim. Ankara: Gündoğan Yayınları.

Timur, T. (2000). Toplumsal değişimler ve üniversiteler. Ankara: İmge Kitabevi.

Tonguç, E. (1970). Devrim açısından köy enstitüleri ve Tonguç. İstanbul: Ant Yayınları.

Tonguç, E. (1997). İsmail Hakkı Tonguç bir eğitim devrimcisi (yaşamı, öğretisi, eylemi). Ankara: Güldikeni Yayınları.

Tonguç, E. (2003). Köy enstitüleri'nin izinde. Ankara: Güldikeni Yayınları.

Tonguç, İ. H. (1938). Canlandirllacak köy. İstanbul.

Tonguç, İ. H. (1946). İlköğretim kavramı. İstanbul: Remzi Kitabevi.

Tonguç, İ. H. (1998). Eğitim yolu ile canlandırılacak köy. Ankara: Köy Enstitüleri Vakfi.

Tonguç, İ. H. (1999). Mektuplarla köy enstitüsü yılları 1936-1946. E. Tonguç (Haz.), Ankara: Güldikeni Yayınları.

Tonguç, İ. H. (2008). Köyde ĕgitim. Ankara: Köy Enstitüleri Vakfi.

Topçu, N. (2015). Türkiye’nin maarif davası. İstanbul: Dergâh Yayınları.

Tozlu, N. (1989). I. H. Baltacıoğlu’nun eğitim sistemi üzerine bir araştırma. İstanbul: Milli Eğitim Basımevi.

Tozlu, N. (1991). Kültür ve eğitim tarihimizde yabancı okullar. Ankara: Akçay Yayınları.

Turan, K. (1992). Mesleki teknik ĕgitimin gelişmesi ve Rüştü Uzel. İstanbul.

Turhan, M. (1964). Maarifimizin ana davaları ve bazı hal çareleri. İstanbul: Bedir Yayınları.

Tutsak, S. (2002). İzmir'de eğitim ve eğitimciler (1850-1950). Ankara: Kültür Bakanlı̆̆1 Yayınları.

Türen, A. Ö. (Haz.). (2018). Köy enstitüleri dosyası Türk Rönesans’ı. İstanbul: Destek Yayınları.

Türer, A. (2011). Türk e ğitim tarihi. Ankara: Detay Yayıncılık.

Türkiye’de eğitim (1990). İstanbul: TÜSİAD Yayınları.

Türkiye’nin eğitim politikası (1990). İstanbul: İstanbul Ticaret Odası Yayınları.

Türkoğlu, P. (1997). Tonguç ve köy enstitüleri. İstanbul: Yap1 Kredi Yayınları.

Tütengil, C. O. (1948). Köy enstitüsü üzerine düşünceler. İstanbul.

Tütengil, C. O. (1969). Türkiye’de köy sorunu. İstanbul.

Unat, F. R. (1927). Maarif düsturu. İstanbul.

Unat, F. R. (1964). Atatürk'ün ögretim hayatı ve yetiştiği devrin milli eğitim sistemi. Ankara: Türk Tarih Kurumu Basımevi. 
Unat, F. R. (1964). Türkiye eğitim sisteminin gelişmesine tarihi bir bakış. Ankara: Milli Eğitim Bakanlığı Yayınları.

Uygun, S. (2007). Tanıkların dilinden bir dönem ögretmen okulları (ilk ögretmen okulları ve köy enstitüleri). Ankara: Milli Eğitim Basımevi.

Uzun, H. (2006). Atatürk ve nutuk. Ankara: Siyasal Kitabevi.

Ülgen, R. (1940). Türk maarif cemiyeti 1928-1940: Çalışmaları ve yaptıkları yardımlar. Ankara: Türk Maarif Cemiyeti.

Ünsal, H. (1980). Milli eğitim ve Atatürk’ün milli eğitim politikası. Ankara: ATASE.

Üskül, M. Z. ve Saylan, T. (Ed.). (1990). Yükseköğretimde sorunlar ve çözümler. İstanbul: Cem Yayınevi.

Widmann, H. (1999). Atatürk ve üniversite reformu. Kazancıgil, A. ve Bozkurt, S. (Çev.), İstanbul: Kabalc1 Yayınları.

Yalçın, O. (1983). Bir eğitimcinin anıları. İstanbul: Yaba Yayınları.

Yamaner, Ş. (1999). Atatürkçü düşüncede ulusal eğitim. İstanbul: Toplumsal Dönüşüm Yayınları.

Y1lmaz, H. T. (1991). Son köy enstitülü. İstanbul: Görkem Yayınları.

Yiğit, A. A. (1992). İnönü döneminde eğitim ve kültür politikası (1938-1950). İstanbul: Boğaziçi Yayınları.

Yücel, H. A. (1994). Türkiye’de orta öğretim. Ankara: Kültür Bakanlığı Yayınları.

Yücel, H. A. (1997). Köy enstitüleri ve köy ĕgitimi ile ilgili yazıları konuşmaları. Ankara: Köy Enstitüleri ve Çağdaş Eğitim Vakfı.

\section{SONUÇ}

Bu makalede Cumhuriyet döneminden günümüze kadar Türk Eğitim Tarihi ile ilgili yayınlanmış olan 341 adet eser yazar soyadına göre bir araya getirilmiştir. Bibliyografya çalışmamızda yer verdiğimiz bu eserlerin içeriğine bakıldığında Türk Eğitim Tarihine yön veren başta Mustafa Kemal Atatürk olmak üzere İsmet İnönü, Hasan Ali Yücel, İsmail Hakk1 Tonguç, İsmail Hakkı Baltacıoğlu, Sitkı Akkay, Cavit Binbaşığlu, Rüştü Uzel, Ziya Gökalp, Rauf İnan, Mustafa Necati gibi kişilerden ve bu kişilerin görüşlerinden, yaklaşımlarından, amaçlarından ve eğitim politikalarından bahsedildiği görülmektedir. Bunun yanı sıra özellikle Cumhuriyet döneminin en önemli eğitim kurumlarından olan köy enstitülerine oldukça geniş yer verilmiştir. Yine bu eserlerde köy enstitülerinin kuruluşundan başlanarak amaçları, ilkeleri, uygulamaları, sorunları üzerinde kapsamlı bir şekilde durulduğu gözlenmektedir. Ayrıca ilk, 
orta ve yüksekokullar ile yabancı okullar, eğitim enstitüleri, üniversiteler, Milli Eğitim Bakanlığı gibi kurum ve kuruluşların amaçları, yöntemleri, ilkeleri, programları, sorunları ve bu sorunlara çözüm önerileri üzerinde çalışmalar yapılmıştır. Bunun yanı sıra eserlerde kamu yararına çalışan dernek statüsünde yer alan ve bir sivil toplum kuruluşu olan halkevleri, halkodaları ve halkevi derneklerinin çalışmaları, faaliyetleri, tüzükleri ve talimatnameleri üzerinde durulmuştur.

Yapılan bu çalışmalar bize Türk Eğitim Tarihi konusunun çok geniş bir perspektifi kapsadığını göstermektedir. Ayrıca tarih ile eğitim birlikte birçok alanda faaliyet gösterdiği için eğitim tarihinin sınırlarını çizmek çok da mümkün görünmemektedir.

\section{Makalenin Bilimdeki Konumu}

Tarih Eğitimi/Türkçe ve Sosyal Bilimler Eğitimi

\section{Makalenin Bilimdeki Özgünlüğü}

Türk Eğitim Tarihi alanında kitap, makale, tez, hatıra gibi birçok çalışmaya rastlanmaktadır. Fakat Türk Eğitim Tarihi konusuyla ilgili literatür taraması anlamında fazla bir çalışma tespit edilememiştir. Bu nedenle 1923 ile 2018 yılları arasında konuyla ilgili kaleme alınan ve kitap haline getirilen eserler kataloglardan ve ilgili tetkik eserlerden incelenerek bu alanda toplu bir literatür oluşturulmaya çalışılmıştır.

\section{KAYNAKÇA}

Balcı, A. (2005). Sosyal bilimlerde araştırma yöntem, teknik ve ilkeler. Ankara: Pegem Yayıncilık.

Karasar, N. (2005). Bilimsel araştırma yöntemi. Ankara: Nobel Yayın Dağıtım.

Bourner, T. (1996). The research process: Four steps to success. Greenfield, T. (Ed.), Research methods: guidance for postgraduatesin (pp. 7-11). London: Arnold.

Ankara Üniversitesi Türk İnk1lâp Tarihi Enstitüsü Kütüphanesi: http://tite.ankara.edu.tr/?page_id=71

Atatürk Üniversitesi Kütüphanesi:http://kutuphane.atauni.edu.tr/yordambt/yordam.php

Aysun-Rafet Ataç Kütüphanesi: http://www.atackutup.com/

Beyazıt Devlet Kütüphanesi: http://www.beyazitdevletkutup.gov.tr/

Bilkent Üniversitesi Kütüphanesi: https://library.bilkent.edu.tr/tr/ 
İstanbul Üniversitesi Kütüphanesi: http://kutuphane.istanbul.edu.tr/tr/

Milli Kütüphane: http://www.mkutup.gov.tr/

Türk Tarih Kurumu Başkanlığı Kütüphanesi: http://kutuphane.ttk.gov.tr/

Ulusal Akademik A ğ ve Bilgi Merkezi Kütüphanesi: http://ulakbim.tubitak.gov.tr/

Van Yüzüncü Y1l Üniversitesi Kütüphanesi:

http://librarycatalog.yyu.edu.tr/client/tr_TR/default

\section{Summary \\ Statement of the Problem}

History of Turkish education includes a wide perspective. Because of history containing lots of departments of education, it is impossible to set boundaries of history of education. However it's possible to see book sections, article, thesis and works on history of Turkish education, there is no catalog on these works. For this reason, a literature study on mentioned subject between 1923 and 2018 is done.

\section{Method}

Literature study is a searching in detail of a subject in works and documents and is a process of collecting data systematically. For Karasar (2005). understanding the problem of research helps the researcher for substantiation of historical perspective. For Balc1 (2005), it is a process of data collecting, discussing on importance of the collected data, understanding relation between the data and the problem and classifying the knowledge.

It's possible to classify literature search as pre-searching and detailed-searching. Presearching is helps researcher to advance an idea, define the topic title and form the method. Detailed-searching is discovering all important, main and other works and in this context deciding the method.

In this study, data are collected by catalog searching and examination of work method. Important catalogs like Milli Library, Turkish Academic Network and Information Center, Beyazit State Library, Turkish History Association, Library of Institute of Turkish Revolution History, Library of Istanbul University, Library of Bilkent University, Library of Ataturk University, Library of Van Yuzuncu Yil University and Library of Aysun-Rafet Ataç are examined. Besides, works of different authors and periodical publications are studied as well. None of the works that published on the subject are ignored but nevertheless it must be accepted that there can be works which have not been published yet. Aditionally, language of works that 
are mentioned in this study are Turkish. Articles, book chapters, presentations and thesis are not included in.

\section{Conclusion}

In this study 341 publications that about history of Turkish education from Republican period to today were gathered with authors' surname. Opinions, approaches, aims and education policies of Mustafa Kemal Atatürk, İsmet İnönü, Hasan Ali Yücel, İsmail Hakkı Tonguç, İsmail Hakkı Baltacıoğlu, Sıtkı Akkay, Cavit Binbaşığlu, Rüştü Uzel, Ziya Gökalp, Rauf İnan, Mustafa Necati are handled. Besides Village Institutes that were the most important education association of Republican period were evaluated. Starting with establishment of the institutes, objectives, principles, applications, problems of the institutes are handled. Further, institutions and organizations like primary school, secondary school, college, foreign schools, educational institutes, universities, Ministry of Education and objectives, methods, principles, programs, problems and solutions to these problems of these institutions and organizations are examined. Moreover, folk houses that work on public benefit and are concidered as association status, folk rooms and works, activities, bylaws and instructions of society of folk houses are handled. 